Revista Brasileira de

Engenharia Agrícola e Ambiental

v.15, n.1, p.96-101, 2011

Campina Grande, PB, UAEA/UFCG - http://www.agriambi.com.br

agriambi Protocolo 091.09 - 16/06/2009 • Aprovado em 22/10/2010

\title{
Estimation of total leaf area in perennial plants using image analysis
}

\author{
Marlon Marcon ${ }^{1}$, Kleber Mariano ${ }^{1}$, Roberto A. Braga ${ }^{1}$, Carlos M. Paglis ${ }^{2}$, \\ Myriane S. Scalco² \& G raham W. H organ ${ }^{3}$
}

\begin{abstract}
One feature of most horticultural crop plants that is biologically relevant to their yield and productivity is total leaf area. How ever, direct methods of estimation of the leaf area cause damage to the plants, whereas indirect methods such as based on light measurement, demand accuracy in the setup of the measurement procedure, which is specific to each crop. Coffee is one of the most important perennial plants related to worldwide trade, and this demands some ability to estimate the productivity of the crop, as well as all the perennial plants involved in production of agricultural products. This study aims to build a model based on indirect measures to estimate the leaf area in coffee plants using image analysis. Two models were evaluated, one based on the height and width of the canopies, and other based on the area of the digital image of a tree. The results of the models have been compared with the real area of the leaves using the destructive approach with measurement of area of all the leaves using a digital scanner. Comparisons between the models and the real values indicated values of adjusted $R^{2}$ of about 0.82 with a model using the height and the width values, and about 0.91 in the second model which used the area projection. The robustness of the model using the height and the width values were tested using data presented in the literature to other cultivars and achieved $R^{2}=0.54$ with an outlier point and 0.91 without it.
\end{abstract}

Key words: non-destructive method, coffee tree, model

\section{Estimativa da área foliar total de culturas perenes por meio de análise de imagens}

\begin{abstract}
RESU MO
A área foliar é um atributo biológico relevante para a produtividade de culturas comerciais. O s métodos diretos de estimação da área foliar causam dano às plantas, enquanto os indiretos, como aqueles baseados na medição da quantidade de luz no interior da planta, exigem ajustes e protocolos de medição específicos para cada tipo de cultura. 0 cafeeiro é uma das mais importantes plantas perenes relacionadas ao comércio de produtos agrícolas em escala mundial, o que demanda habilidade de estimar sua produtividade, tal como ocorre para as outras culturas perenes. Este trabalho visa construir um modelo que contenha um método indireto de estimativa de área foliar em cafeeiros por meio da análise de imagens. Dois modelos foram analisados, sendo que em um foram usadas a altura e a largura dos dosséis e, no outro, se baseou na área projetada do dossel. Os resultados foram comparados com o método direto, através do qual se retiraram todas as folhas dos cafeeiros o que permitiu observar valores de $\mathrm{R}^{2}$ ajustado de 0,82 para o modelo em que se usaram a altura e a largura dos dosséis, e de 0,91 para o modelo da área projetada. A robustez do método da altura e largura foi testada usando-se dados de literatura relativos a outra cultivar oferecendo valores de $\mathrm{R}^{2}$ de 0,54 , considerando-se um ponto fora da curva, e de 0,91 sem se considerar este ponto.
\end{abstract}

Palavras-chave: método não destrutivo, cafeeiro, modelo

\footnotetext{
${ }^{1}$ DEG/UFLA, CP. 3037, CEP 37.200-000, Lavras, MG. Fone: (35) 3829-1481. E-mails: marlon_marcon@hotmail.com, robbraga@deg.ufla.br, klebermariano@gmail.com

2 DAG/UFLA, CP. 3037, CEP 37.200-000, Lavras, MG. Fones: (35) 3829-1301. E-mails: msscalco@dag.ufla.br, paglismau@dag.ufla.br BioMathematics Statistics Scotland, Rowett Research Institute, Bucksburn, AB21 9SB Aberdeen Scotland. E-mail : g.horgan@abdn.ac.uk
} 


\section{INTRODUCTION}

As foliage is an important plant organ, the main one involved in the photo-synthetic process of converting solar to chemical energy, and in the process of evapotranspiration, leaf area monitoring is an important tool in studying physiological features related to plant growth, and photosynthetic and transpiration processes, as well as being a helpful index in evaluating damage caused by leaf diseases and pests and in the effects of the culture management and treatments (Fidelis Filho et al., 2010; Monteiro et al., 2005; Tavares Júnior et al., 2002; Favarin et al., 2002). In addition, leaf area estimation plays a key factor in forecasting production (Lizaso et al., 2003) improving the actions of setting prices and the management of production, storage and selling. In particular, Tavares Júnior et al. (2002) presented irrigation management as a practical example of the usefulness of the leaf area estimation.

Leaf area determination can be done by direct methods, which involve measuring all the individual leaf areas, or indirect methods, which are based on the relation of some plant characteristics with the true leaf area obtained in destructive tests. In comparing the direct and indirect methods, we note the latter to be generally non-destructive techniques (NDT), and the former to be time-consuming in removing and preparing all the leaves (Coelho Filho et al., 2005).

One of the results of the indirect methods is known as the leaf area index (LAI), which has been used widely by researchers and producers. Favarin et al. (2002) evaluated the relation between some measures of the coffee plant (Coffea arabica L.) and its LAI, and showed that reliable information can come from the estimated volume or area of the canopy, and that it is also possible to get estimates from the height and diameter of the canopy, all of them closely correlated with true leaf area, with $\mathrm{R}^{2}$ over 0.97 .

According to Vieira Júnior et al. (2006) many traditional methods and associated equipment have been replaced by computational approaches using digital image analysis, and this has been found to be a reliable tool to provide indirect measurements. Examples of that alternative use of digital image analysis to agricultural measurements were presented by Rabelo et al. (2005) and Botega et al. (2009) adopting the laser and optics techniques to evaluate orange fruits and leaves of coffee respectively.

Contrast is a factor of special importance in image analysis, and a useful image must provide the ability to distinguish the most important features, such as separating the object from the background. A low contrast image can, in some cases, be improved using some approaches such as stretching the histogram or changing the final contrast and brightness, to give the image a new distribution of intensity frequencies (Gonzalez \& Woods, 2008). The isolation of the object from the background is usually done by thresholding, basically determining the areas with two distinct ranges of gray levels, in particular the Otsu Thresholding (Pratt, 2007).

Coffee is one of the most important agricultural products worldwide which comes from perennial plants. As a commodity, its production is monitored in order to estimate its availability, and an important predictor can be provided by estimation of leaf area in whole plants in a crop. The challenge is then to present a methodology or equipment to improve the estimation with reduced time, reduced cost and with reliable results.

Digital image analysis of the coffee crop has been mainly limited so far to the leaves. It is presented by Guzman et al. (2003) in evaluating the damaged area of leaves, allowing precise and fast results. The measure of a leaf using images and interactive computer software was presented by Igathinathane et al. (2006) as well. In other crops, the use of image analysis of leaf area has been described, such as, the leaf area coverage in Chichorium intybus L. demonstrated by Zhang et al. (2003), as well as in Brassica napus L. by Behrens \& Diepenbrock (2006). In turn, the Leaf Area Index (LAI) is one useful index provided by a commercial equipment, which deals with optics and images analysis. Its use in a perennial crop, such as in olive trees, presented a $\mathrm{R}^{2}$ between 0.73 and 0.86 when comparing the LAI values with the total leaf area (Simões et al., 2007). Ushada et al. (2007) presented an approach based on neural networks to monitor canopy parameters, such as leaf area index, from digital images. The samples were restricted to immature plants and monitored in laboratory, as well as the images collected from the canopy top. Another approach using images to estimate leaf area adopted the stereo vision as a tool to get geometric properties of 10 young plants with 5 to 6 leaves (Andersen et al., 2005).

This work aimed to present an alternative technique for estimation of the leaf area of perennial trees inside a commercial crop using image analysis, proposing models that deliver rapid results with robust approaches. Two models were built using the width and the height of coffee tree canopies obtained from digital images, as well as the total visible leaf area computed from the same images, comparing both with the real values from the summation of all leaf areas, and testing one model with data presented in the literature.

\section{MATERIAL AND METHODS}

\section{Data acquisition}

The data has been imaged and collected from a coffee crop with commercial characteristics in an area of $1920 \mathrm{~m}^{2}$ with about 1280 plants of Topazio MG-1190 cultivar. The crop received ferti-irrigation and the plants had spacings of 2.5 by $0.6 \mathrm{~m}$. High productivity with high vegetative vigour are two critical features of this cultivar, which do not present significant reduction in its production, even after a large harvest. Its secondary branches are abundant and with higher angles, allowing better aeration and illumination inside the tree Carvalho et al. (2003). The ranges of the canopies adopted in the work varied from young plants with $0.24 \mathrm{~m}$ heights, to two year old plants with $1.82 \mathrm{~m}$ heights in a total of 42 samples. The leaves of the trees were taken off, after the imaging process conducted in the loci of the crop, and then the total leaf area was measured using a commercial scanner, the Leaf Area Meter (Li-Cor LI 3100 ), which has been shown to have a precision of $99 \%$ (LiCor, 1996). The images were obtained using a digital camera with a resolution of 640 ' 480 pixels, as it is possible to see in Figure 1. 


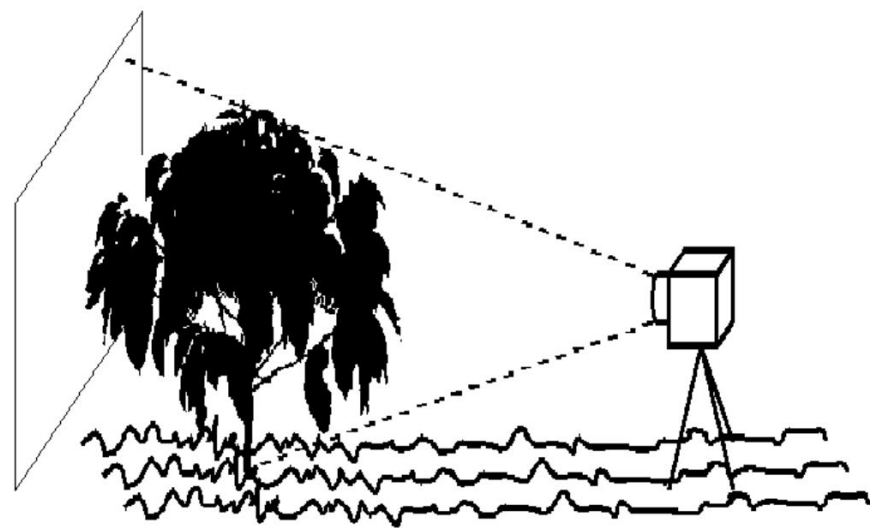

Figure 1. Design of image capture of a tree

\section{Image processing}

The images were corrected by normalizing their frequency histograms by stretching the middle $90 \%$ of the histogram to the full range of intensities. After brightness and contrast correction, the images were scaled using a reference card included in the background behind the plants. Thresholding was then done using the Otsu method, the last step of the segmentation process.

\section{Identification of the image characteristics}

The characteristics obtained from the images were: projection area, width and height. Figure 2 shows an original image with an indication of the characteristics used.

A.

B.
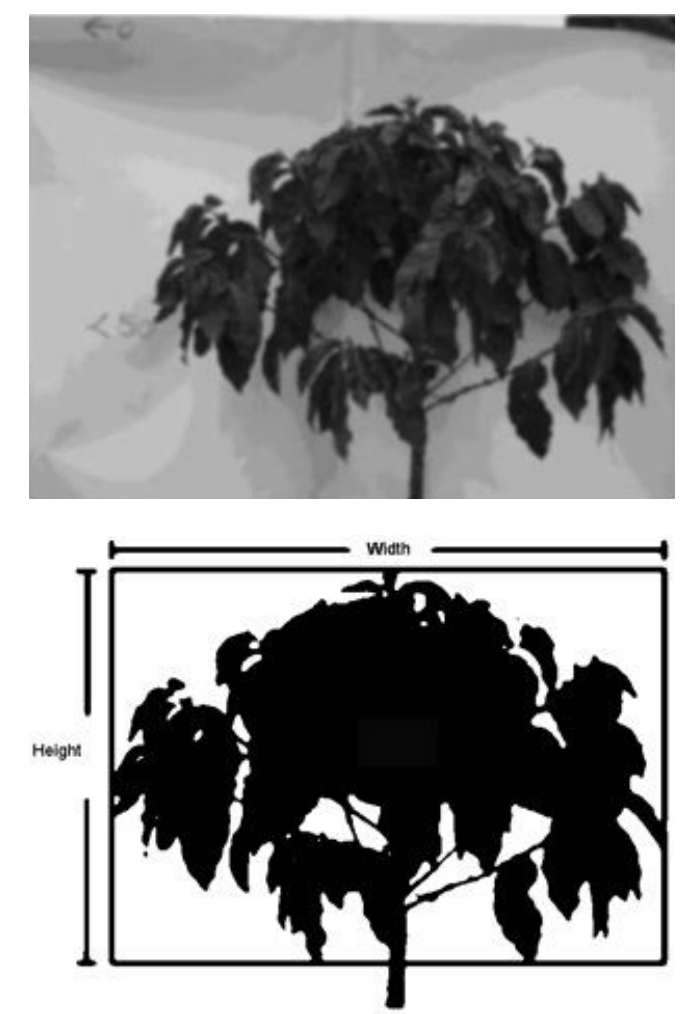

Figure 2. Example of image analysis with (A) the original image of the plant and its background, and (B), the processed image, with the indication of how the area, width and height were obtained

\section{Leaf area estimation models}

The prediction of the leaf area from the largest width and height of the canopy was defined as the first model (WHMvsRA), and the prediction of the leaf area from the projection area, measured from digital images, was considered as the second model (PAMvsRA). Both methods considered the destructive method, which measures the real area of the all leaves, as a reference.

Width and height model (WHM) versus real area: Model parameters were estimated by fitting a curve which has the width (w), and the height (h) as the image characteristics. A quadratic association was fitted, as the coffee plant canopy is three dimensional and so the total leaf area might be expected to depend at least on the square of the size measurements:

$$
f(h, w)=a h^{2}+b w^{2}+c h w+d h+e w+f
$$

where the function $\mathrm{f}(\mathrm{h}, \mathrm{w})$ is the predicted leaf area, and the values $a, b, c, d$, e and $f$ are the coefficients of the equation that is obtained by the fitting process, which was done by the least square method. To avoid overfitting with a modest sample size, we did not investigate stepwise selection to refine the model by removing non-significant terms, but use the adjusted $R^{2}$ to indicate how well LAI can be predicted from $\mathrm{h}$ and $\mathrm{w}$.

Projection area model (PAM) versus real area: The second model compared the projection area obtained from the images with the real area from all the leaves scanned. In this case there is only one prediction variable, and we examined different fitting curves such as linear, logarithmic, quadratic, power and exponential.

\section{Testing the WHM}

The robustness of the first model was conducted using a collection of data from an account with characteristics of coffee trees considering height, width and real leaf area measured by Li-Cor equipment (Favarin et al., 2002). The trees analyzed in that report were of the Mundo Novo cultivar (IAC 388-17) with plant height from 0.50 to $1.29 \mathrm{~m}$. This cultivar presents a taller structure compared with the Topazio one, used in this work to build the models.

\section{RESULTS AND DISCUSSION}

\section{Width and height model versus real area (WHMvsRA)}

The fitting process to height and width values resulted in a regression equation:

$f(h, w)=-2.11 h^{2}-4.34 w^{2}+8.36 h w-2.11 h+3.97 w-1.16$

where the $\mathrm{f}(\mathrm{h}, \mathrm{w})$ is the value representing the leaf area, as a function of height $(\mathrm{h})$ and width $(\mathrm{w})$. The value must be divided by 10000 in order to get the value in meters $(\mathrm{m})$.

Figure 3 presents the association between the real and predicted plant values, with the diagonal line showing the model proposed, and with the adjusted $\mathrm{R}^{2}$ value around 0.91 . 
Figure 4 shows the fitted model in a quadratic surface. The comparison of the model to the actual leaf area achieved by the destructive method presented an adjusted curve with a high $\mathrm{R}^{2}$ considering the great variability expected in biological material as well as considering the use of just two variables that can be obtained even manually.

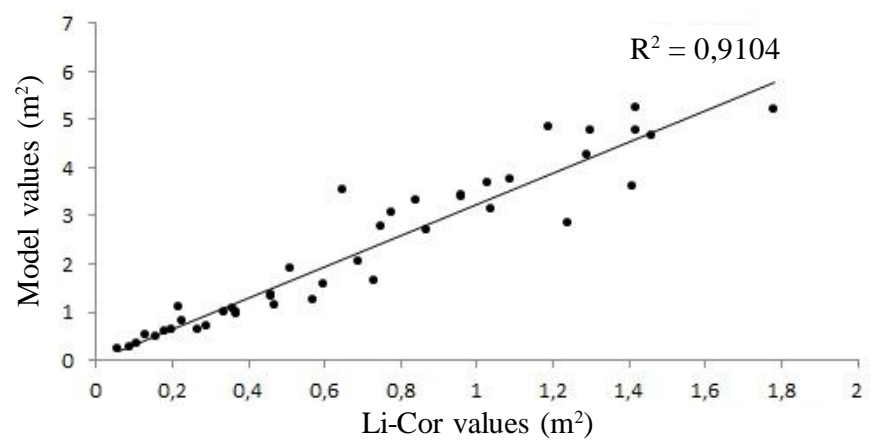

Figure 3. Dispersion values of the real plant values with respect to the model in the diagonal

$f(h, w)=-2.11 h^{2}-4.34 w^{2}+8.36 h w-2.11 h+3.97 w-1.16$

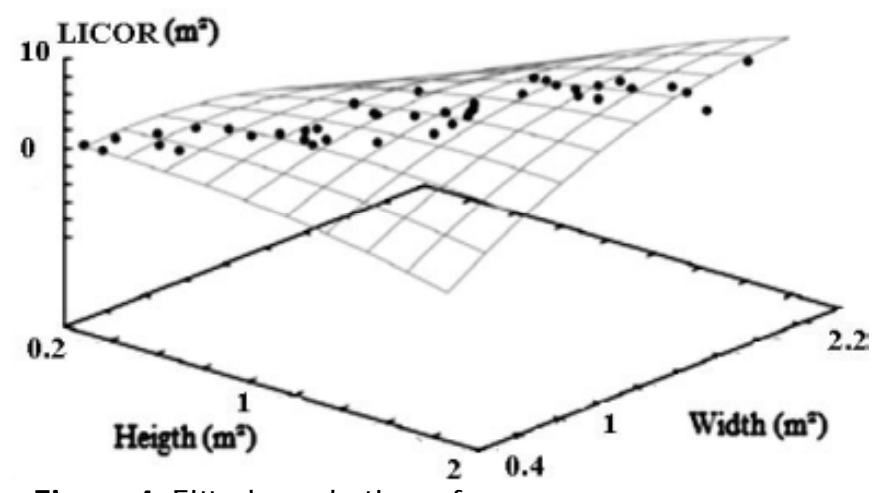

Figure 4. Fitted quadratic surface

The values of the plants' sizes and leaf areas from Li-Cor are shown in Table 1, in order to help as a base for further enhancements of the model, or even for validations.

The height and width values, measured in the account presented by Favarin et al. (2002), have been tested in the Width and Height Model (WHM), and the $\mathrm{R}^{2}$ observed was 0.54 to the whole data, plotted in Figure 5, and 0.91 without an outlier which represents a plant with a non-characteristic shape. It should be considered that the small size of the data amplifies the influence of the outlier in this analysis, though the testing was conducted with a cultivar with a different shape. Nevertheless, the absence of the outlier offered a high value of $\mathrm{R}^{2}$, which can encourage the use of this approach to a wider range of cultivars, and as well to other species.

\section{Projection area model (PAM) versus real area}

Table 2 presents the curves fitted to the projection areas computed from the images versus the real area values. The five curves present good adjusted $\mathrm{R}^{2}$, with a large deviation observed in respect to the exponential curve. There is little benefit from including a quadratic term, and a linear prediction
Table 1. Values of the plants sizes and leaf areas from Li-

\begin{tabular}{cccccccc} 
Cor & & & & & & & \\
\hline Plant & Width & Height & LiCor & Plant & Width & Height & LiCor \\
1 & 1.96 & 1.55 & 2.83 & 22 & 0.94 & 0.77 & 0.61 \\
2 & 1.75 & 1.82 & 4.74 & 23 & 1.39 & 1.09 & 1.65 \\
3 & 1.68 & 1.32 & 3.14 & 24 & 1.26 & 0.71 & 1.31 \\
4 & 2.16 & 1.64 & 5.19 & 25 & 0.90 & 0.70 & 1.08 \\
5 & 1.92 & 1.52 & 3.58 & 26 & 1.19 & 0.87 & 1.89 \\
6 & 1.62 & 1.36 & 4.81 & 27 & 1.20 & 1.11 & 1.55 \\
7 & 1.70 & 1.11 & 3.43 & 28 & 1.04 & 1.00 & 1.14 \\
8 & 1.63 & 1.45 & 4.24 & 29 & 0.96 & 0.85 & 1.07 \\
9 & 1.69 & 1.17 & 3.68 & 30 & 0.89 & 0.85 & 1.00 \\
10 & 1.67 & 1.23 & 3.75 & 31 & 1.02 & 0.76 & 0.96 \\
11 & 1.74 & 1.45 & 5.22 & 32 & 0.84 & 0.53 & 0.82 \\
12 & 1.75 & 1.49 & 4.63 & 33 & 0.59 & 0.53 & 0.59 \\
13 & 1.69 & 1.40 & 4.75 & 34 & 1.49 & 0.79 & 1.25 \\
14 & 1.39 & 1.12 & 3.29 & 35 & 0.60 & 0.44 & 0.48 \\
15 & 1.16 & 1.06 & 3.54 & 36 & 0.98 & 0.74 & 0.98 \\
16 & 1.28 & 1.09 & 3.04 & 37 & 0.67 & 0.37 & 0.53 \\
17 & 1.34 & 1.16 & 3.37 & 38 & 0.85 & 0.62 & 0.70 \\
18 & 1.40 & 1.09 & 2.04 & 39 & 0.79 & 0.43 & 0.62 \\
19 & 1.60 & 1.15 & 2.70 & 40 & 0.45 & 0.32 & 0.25 \\
20 & 1.23 & 1.16 & 2.75 & 41 & 0.56 & 0.28 & 0.32 \\
21 & 1.23 & 0.82 & 1.36 & 42 & 0.45 & 0.24 & 0.23 \\
\hline
\end{tabular}

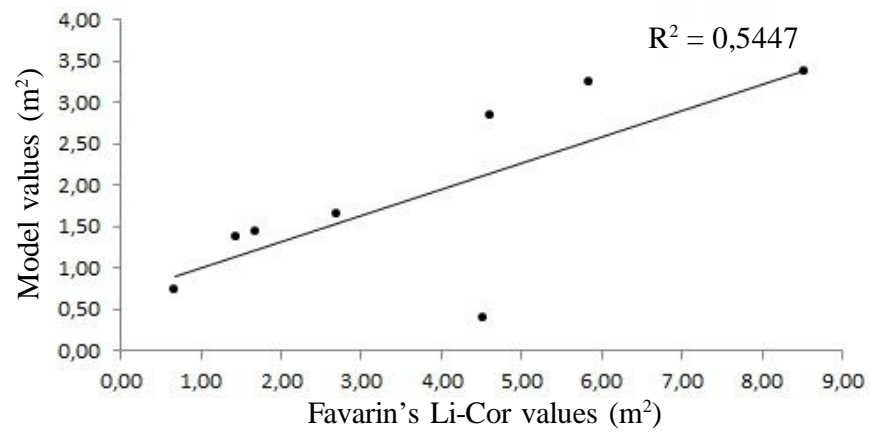

Figure 5. Dispersion values of the tested data submitted to the model

based on the projection area appears to do almost as well. The small improvements by using non-linear terms can be understood from the three-dimensional nature of the tree canopy.

Table 2. Results of different curve adjustments to Projection Area Model

\begin{tabular}{lll}
\hline Model & \multicolumn{1}{c}{ Formula $\left(\mathbf{m}^{2}\right)$} & $\mathbf{R}^{\mathbf{2}}$ \\
Linear & $3.25 \mathrm{x}-0.005$ & 0.91 \\
Logarithmic & $1.64 \ln (\mathrm{x})+3.33$ & 0.80 \\
Quadratic & $-0.45 \mathrm{x}^{2}+3.97 \mathrm{x}-0.20$ & 0.91 \\
Power & $3.163 \mathrm{x}^{1.004}$ & 0.95 \\
Exponential & $0.486 \mathrm{e}^{1.745 x}$ & 0.84 \\
\hline
\end{tabular}

The Width and Height Model (WHM) presented a $\mathrm{R}^{2}$ value (0.91) near to that achieved by Simões et al. (2007) using the LAI approach with a commercial equipment (0.73-0.86) to predict the leaf area of an olive crop. The proposed methods in this work present the advantage of demanding low cost equipments. In the limit, WHM is a robust method and can be implemented by just measuring the plant manually, with particular care in the creation of a standard procedure to avoid human interference in the measurements. In addition, the 
requirement of only a computer as material to implement the prediction using the model makes the protocol proposed here as an accessible tool to farmers and researchers.

The Projection Area Model (PAM) presented better correlations compared with the total leaf area measured by a time consuming and fastidious approach, which illustrate the potential of that method in the leaf area analyzes. The results encourage the spread of the technique to other perennial plants, in this case, considering a correlation between the production and the proposed models as a validation procedure, avoiding the necessity to take off all the leaves.

Some challenges are expected to be over crossed, such as the adjustment of the models to density of the crops, and as well to mature crops. The rare literature about the monitoring of leaf area in medium size plants, and the large work demanded to monitor perennial plants with huge amount of leaves and long periods of life can be the explanation of the difficulties to achieve the results in a short period. The effort to get more information using indirect approaches will be a relevant area of work in leaf area prediction, and certainly will need the association of other variables to avoid external influences such as the human subjectivity, the non-homogeneity of the crowns and the lack of a protocol. The access of the light transmittance in the crown would be a line of analysis, which can be used to weight the model, increasing the ability of the proposed technique, to adapt itself to stages of the plant and to seasons of the year. The use of commercial instruments dedicated to forest leaf area analysis and techniques such as hemispherical photography should be evaluated to be adapted to medium size crowns and compared to the efficiency of the proposed model and to the gold standard method, which is time consuming and destructive.

\section{Conclusions}

1. The work has presented the ability to build models to estimate the leaf area with reliable results in a perennial crop using image analysis techniques and dimensions of the plants, and therefore using non-destructive techniques.

2. The Width and Height Model (WHM) presented a fitting with a $\mathrm{R}^{2}$ of 0.91 compared to the real total leaf area, and the Projection Area Model (PAM) showed a $\mathrm{R}^{2}$ of 0.91 related tho the same real reference.

3. The WHM was tested, in addition, with data from literature of a distinct cultivar of coffee and presented fitting curves with $\mathrm{R}^{2}$ of 0.54 and 0.91 depending on the presence or not of an outlier point represented by a plant out on the medium characteristics.

\section{ACKNOWLEDGEMENTS}

This work was partly supported by the CNPq (DT and Universal07), by the CAPES, by the FAPEMIG - Brazil, and by the Scottish Government Rural and Environment Research and Analysis Directorate.

\section{LITERATURE CITED}

Andersen, H. J.; Reng, L.; Kirk, K. Geometric plant properties by relaxed stereo vision using simulated annealing. Computers and Electronics in Agriculture, v.49, p.219-232, 2005.

Behrens, T.; Diepenbrock, W. Using digital image analysis to describe canopies of winter oilseed rape (Brassica napus L.) during vegetative developmental stages. Journal of Agronomy Crop Science, v.192, n.4, p.295-305, 2006.

Botega, J. V. L.; Braga, R. A.; Machado, M. P. P.; Lima, L. A.; Faria, R. O. Avaliação da interferência do laser no material biológico vivo. Revista Brasileira Engenharia Agrícola e Ambiental, v.13, n.4, p. 483-486, 2009.

Carvalho, H. P.; Melo, B.; Marcuzzo, K. V.; Teodoro, R. E. F.; Severina, G. M. Avaliação de cultivares e linhagens de café (Coffea arabica L.) nas condições de cerrado em UberlândiaMG. Bioscience Journal, v.19, p.59-68, 2003.

Coelho Filho, M. A.; Angelocci, L. R.; Vasconcelos, M. R. B.; Coelho, E. F. Estimativa da área foliar de plantas de lima ácida 'Tahiti' usando métodos não-destrutivos. Revista Brasileira de Fruticultura, v.27, n.1, p.163-167, 2005.

Favarin, J. L.; Dourado Neto, D.; García, A. G. Y.; Nova, N. A. V.; Favarin, M. G. G. V. Equações para a estimativa do índice de área foliar do cafeeiro. Pesquisa Agropecuária Brasileira, v.37, n. 6, p.769-773, 2002.

Fideles Filho, J.; Beltrão, N. E. de M.; Pereira, A. S. Desenvolvimento de uma régua para medidas de área foliar do algodoeiro. Revista Brasileira Engenharia Agrícola e Ambiental, v.14, n.7, p.736-741, 2010.

Gonzalez, R. C.; Woods, R. E. Digital image processing. 3.ed. Upper Saddle River: Prentice Hall, 2008.954p.

Guzman, O. A. P.; Gomez, E. O. G.; Rivillas, C. A. O.; Oliveros, C. E. T. Utilización del procesamiento de imágenes para determinar la severidad de la mancha de hierro en hojas de café. Cenicafé, v.54, n.3, p.258-265, 2003.

Igathinathane, C.; Prakash, V. S. S.; Padmab, U.; Ravi Babub, G.; Womac, A. R. Interactive computer software development for leaf area measurement. Computers and Electronics in Agriculture, v.51, p.1-16, 2006.

Lizaso, J. I.; Batchelor, W. D.; Westgate, M. E. A leaf area model to simulate cultivar-specific expansion and senescence of maize leaves. Field Crops Research, v.80, n.1, p.1-17, 2003.

Li-Cor LI-3100 area meter instruction manual. Lincoln: LI-COR, 1996.34p.

Monteiro, J. E. B. A.; Sentelhas, P. C.; Chiavegato, E. J.; Guiselini, C.; Santiago, V. A.; Prela, A. Estimação da área foliar do algodoeiro por meio de dimensões e massa das folhas. Bragantia, v. 64, n.1, p.15-24, 2005.

Pratt, W. K. Digital image processing, 4.ed. New York: Wiley \& Sons, 2007. 812p.

Rabelo, G. F.; Braga, R. A.; DalFabbro, I. M.; Trivi, M. R.; Rabal, H. J.; Arizaga, R. Laser speckle techniques in quality evaluation of Orange fruits. Revista Brasileira Engenharia Agrícola e Ambiental, v.9, n.4, p.570-575, 2005.

Russ, J. The image processing handbook, 3.ed. New York: CRC Press, 1999. 832p.

Simões, M. P.; Cruz, C. P.; Belo, A. F.; Ferreira, L. F.; Neves, J. P.; Castro, M. C. Utilização de fotografia hemisférica na determinação do índice de área foliar de oliveiras jovens (Olea europaea L.). Revista de Ciências Agrárias, v.30, n.1, p.527-534, 2007. 
Tavares Júnior, J. E.; Favarin, J. L.; Dourado Neto, D.; Maia, A. H. N.; Fazuoli, L. C.; Bernardes, M. S. Análise comparativa de métodos de estimativa de área foliar em cafeeiro. Bragantia, v.61, n.2, p.199-203, 2002.

Ushada, M.; Murase, H.; Fukuda, H. Non-destructive sensing and its inverse model for canopy parameters using texture analysis and artificial neural network. Computers and Electronics in Agriculture, v.57, p.149-165, 2007.
Vieira Júnior, P. A.; Dourado Neto, D.; Cicero, S. M.; Castro Jorge, L. A.; Manfron, P. A.; Martin, T. N. Estimativa da área foliar em milho através de análise de imagens. Revista Brasileira de Milho e Sorgo, v.5, n.1, p.58-66, 2006.

Zhang, M.; Baerdemaeken, J. de; Schreven, E. Effects of different varieties and shelf storage conditions of chicory on deteriorative color changes using digital image processing and analysis. Food Research International, Toronto, v.36, p.669-673, 2003. 